\title{
Activin A and follistatin: their role in the acute phase reaction and inflammation
}

\author{
D $\mathbf{M}$ de Kretser, $\mathbf{M} \mathbf{P}$ Hedger and $\mathbf{D}$ J Phillips
}

Institute of Reproduction and Development, Monash University, Clayton, Victoria, Australia

(Requests for offprints should be addressed to D M de Kretser, Institute of Reproduction and Development, Monash Medical Centre, Block E Level 3, 246 Clayton Road, Clayton, Victoria, Australia 3168)

The activins are a family of proteins which consist of disulphide-linked homodimers and heterodimers of the $\beta$ subunits of inhibin termed $\beta_{\mathrm{A}}$ and $\beta_{\mathrm{B}}$. These three proteins, called activin $A\left(\beta_{A}-\beta_{A}\right)$, activin $B\left(\beta_{B}-\beta_{B}\right)$ and activin $\mathrm{AB}\left(\beta_{\mathrm{A}}-\beta_{\mathrm{B}}\right)$, are members of the transforming growth factor $\beta$ (TGF $\beta$ ) super-family of proteins (de Kretser \& Robertson 1989). Recently, three additional members of this family have been identified, called $\beta_{C}, \beta_{D}$ and $\beta_{\mathrm{E}}$, but as yet their actions remain to be defined (see Fang et al. 1996 for review). The physiological roles of this family of proteins are largely based on the established properties of activin $A$, as sufficient supplies of this protein have been made available in recombinant form.

Although the activins were originally isolated for their ability to stimulate follicle-stimulating hormone secretion, they have been shown to influence many biological processes, including parenchymal haemopoiesis, embryogenesis, neurotransmission, hepatic parenchymal cell division, prostate biology and angiogenesis. Some of the actions of activin $\mathrm{A}$ are antagonised by inhibin $\mathrm{A}$, which is a dimer of the $\beta_{\mathrm{A}}$ subunit with its $\alpha$ subunit, and inhibin $\mathrm{B}$, an $\alpha-\beta_{\mathrm{B}}$ dimer.

The actions of activin A are expressed through a system of specific transmembrane serine-threonine kinase receptors which exist in two subgroups, type I and type II, both of which are essential for activin to act (ten Dijke et al. 1996). Further regulation of the actions of the activins is achieved through follistatin, a protein which binds activin $\mathrm{A}$ and $\mathrm{B}$ with high affinity and neutralises its biological activity (Nakamura et al. 1990, Phillips \& de Kretser 1998 for review). It is not known whether follistatin binds $\beta_{\mathrm{C}}$, $\beta_{\mathrm{D}}$ and $\beta_{\mathrm{E}}$. Additionally, the factors which regulate the balance of production between the inhibins and activins also represent a mechanism modulating activin A levels and thus its biological activity.

The involvement of activin and follistatin in the response to trauma and inflammation emerged from the capacity of activin, like TGF $\beta$, to suppress T cell activation (Hedger et al. 1989) and from the rise in follistatin induced in response to surgical stress (Klein et al. 1993). In the intervening years, a considerable body of evidence has accumulated to support the involvement of both activin and follistatin in inflammation and the acute phase reaction.

Tissue injury and inflammation are accompanied by the release of the cytokines interleukin (IL)-1, IL-6 and tumour necrosis factor $\alpha$ (TNF $\alpha$ ) from macrophages and stromal cells at the site of injury (Steel \& Whitehead 1994). These cytokines, in turn, act at systemic sites, in particular the liver, to activate gene expression and the febrile response to injury, collectively known as the acute phase response (APR). The APR is a response to injury which induces numerous changes designed to protect the host and, in turn, to limit the potentially widespread actions of the cytokines and acute phase proteins released (Steel \& Whitehead 1994). The acute phase proteins (APP) that are up-regulated include agents which limit the inflammatory process, minimise tissue damage and facilitate the repair process. Included in this group are metal binding proteins, coagulation proteins, complement proteins, proteinase inhibitors and others such as serum amyloid A, serum amyloid $\mathrm{P}$ component and $\mathrm{C}$-reactive protein. In addition, IL-1 and IL-6 act on the pituitary-adrenal axis to induce glucocorticoid secretion, which facilitates APP secretion and inhibits cytokine gene expression by monocytes and macrophages.

Several observations have linked the activin A/follistatin system to the modulation of the APR. While our studies established that the pattern of follistatin secretion was similar to that of an APP (Klein et al. 1993, Phillips et al. 1996), its role in this process remained unclear, since no data were available to demonstrate a role for activin A in this process, partly due to difficulties in assaying this protein. However, recently Brosh et al. (1995) showed that activin A was an IL-6 antagonist at a number of sites, and established that this action was probably mediated by interference with the signal transduction mechanism of IL-6. Further, activin A decreases IL-1 $\beta$ production and 
induces IL-1 receptor antagonist secretion by human monocytic cells, effectively acting as a negative IL-1 modulator (Ohguchi et al. 1998). However, it is important to note that activin A stimulates IL-6 production by monocytes (Yamashita et al. 1993).

The demonstration that activin A can antagonise the actions of both IL-1 and IL-6 raises the possibility that activin A acts as an anti-inflammatory agent both locally at the site of injury or infection and at peripheral sites such as the liver. In turn, the actions of activin A, a pleotrophic cytokine or growth factor, is subject to regulation by a multiplicity of systems, one of which is its binding protein, follistatin.

\section{What are the roles of activin A and follistatin in inflammation and the APR?}

\section{At the site of tissue injury}

Increased activin A expression, as either mRNA or protein, has been shown at sites of tissue injury, in chronic inflammatory bowel disease or in synovial fluid from patients with inflammatory arthropathy (Hubner et al. 1997, Yu et al. 1998). The likely cellular localisation at these sites is fibroblasts (Hubner et al. 1997), but other studies have shown that macrophages and monocytes produce activin A in response to lipopolysaccharide (LPS) and proinflammatory cytokines such as $\gamma$ interferon and granulocyte monocyte colony stimulating factor (Eramaa et al. 1992, Shao et al. 1992). At these sites, activin A has the potential to antagonise the local actions of IL- 6 and IL-1. Additionally, activin A and follistatin are expressed in endothelial cells and follistatin has been shown to induce angiogenesis (Kozian et al. 1997). The temporal and cellular expression of activin A and follistatin will be required to determine whether the differential regulation of these proteins after wound healing (Hubner et al. 1996) has a role to play in the control of vascular integrity after tissue injury or whether they are involved in the modulation of IL-1 and IL-6 at these sites.

\section{In the circulation}

Follistatin levels in the circulation rise 6-24 h post-surgery with peak levels at approximately $12 \mathrm{~h}$ in ewes (Klein et al. 1993) and in rams (Phillips et al. 1996). Further, Michel et al. (1998) have shown that follistatin levels in the circulation are markedly elevated in patients with septicaemia.

Support for the concept that this rise in follistatin is linked to the APR emerges from studies which demonstrated that IL-1 $\beta$ injection could induce a similar circulating rise in this protein (Phillips et al. 1996). Further, administration of LPS to sheep resulted in a marked increase in serum follistatin levels, showing the capacity of an inflammatory stimulus to increase follistatin expression (Klein et al. 1996). However, during a sustained inflammatory stimulus induced by the administration of yeast to lambs, follistatin levels rose initially for about $24 \mathrm{~h}$, but subsequently declined (Phillips et al. 1998). The failure to sustain the increased follistatin expression may have been related to the intervention of other pathways regulating follistatin, since we showed that the weight loss sustained by the lambs in this experiment probably served as a negative regulator of follistatin. The source of follistatin secretion in the acute phase response still remains unclear. Hepatic parenchymal cells express follistatin mRNA and hepatoma cells (HepG2) can secrete follistatin in response to activin but not IL-1 $\beta$ (Phillips et al. 1998). However, Michel et al. (1996) showed that follistatin mRNA in endothelial cells increases markedly following LPS stimulation, raising the possibility that these cells may be the site of the follistatin response.

There are still no published data concerning systemic activin A levels in response to agents inducing the APR. The administration of LPS has been shown to cause an acute and rapid increase in activin A levels between 0.5 and $4 \mathrm{~h}$ later and this precedes the rise in follistatin (K L Jones, D M de Kretser \& D J Phillips, unpublished observations). These data need to be expanded further to document changes in activin A levels resulting from a variety of stimuli.

The significance of the changes in circulating follistatin and activin A levels remains to be established. Given the capacity of activin A to antagonise the actions of IL-6 and IL-1, the increased serum levels of activin A may modulate the actions of these cytokines at many sites and, in particular, the stimulatory actions of these cytokines on acute phase protein production in the liver. Failure of activin A to modulate the actions of these cytokines may be linked to the continued elevated levels of some of the acute phase proteins which have been implicated in chronic disease states such as secondary amyloidosis (Steel \& Whitehead 1994). Additionally, activin A may stimulate erythroid and megakaryocyte differentiation in the bone marrow, negating the effects of infection and trauma at these sites (for review see $\mathrm{Yu} \&$ Dolter 1997).

It is unclear whether activin A can penetrate the blood-brain barrier, as microinfusions of activin A into the paraventricular nucleus in rats can cause the release of corticotrophin releasing hormone $(\mathrm{CRH})$ and oxytocin (Plotsky et al. 1991). The resultant stimulation of adrenal glucocorticoid secretion could exert modulatory influences on the APR and the inflammatory state. Further, LPS has been shown to induce cFOS expression at numerous central nervous system sites including the paraventricular nucleus and the nucleus tractus solitarius, which projects to the paraventricular nucleus and probably uses activin A as a neurotransmitter (Sawchenko et al. 1988, Hare et al. 1995). 


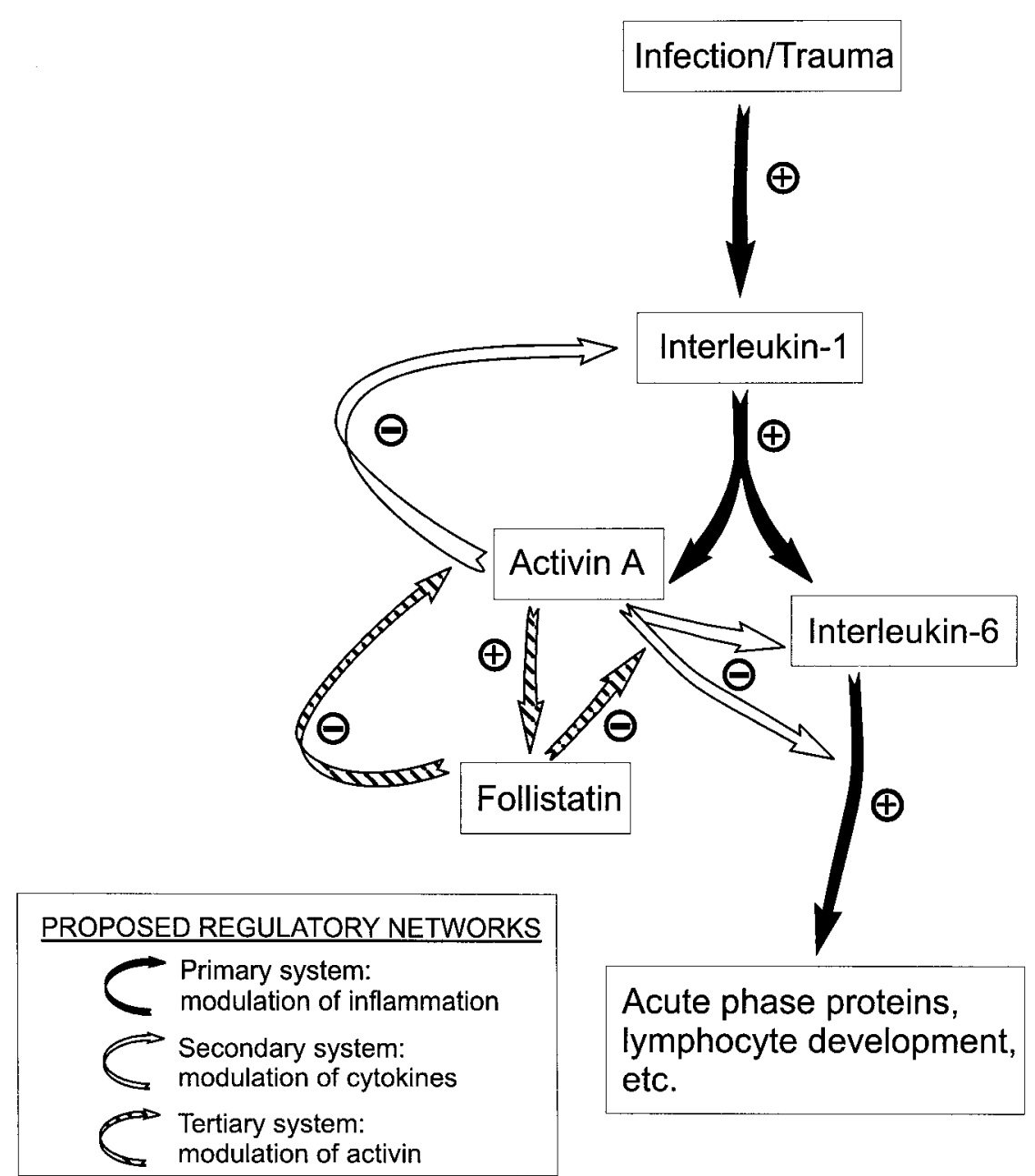

Figure 1 This diagram illustrates the interrelationships between activin A, follistatin and the proinflammatory cytokines, IL-1 and IL-6.

\section{In the liver}

The APR is characterised by a marked increase in hepatic acute phase protein production under the influence of IL-1 and IL-6, and Brosh et al. (1995) have shown that activin A can inhibit the IL-6-induced stimulation of some of these proteins. In recent studies using HepG2 cells, we have shown that activin A can directly inhibit the secretion of haptoglobin and block the stimulatory action of IL-6 on this process, yet it could only inhibit $\alpha 1$-acid glycoprotein production indirectly by its antagonistic action on IL-6 (Russell et al. 1999). Further, these studies showed that activin A stimulated HepG2 cell secretion of follistatin which, in turn, could modulate the action of activin. There is a need for further studies to document the actions of activin A on the full range of APR proteins, given their important role in modulating the body's response to the inflammatory or traumatic stimulus.
What is the integrative role of activin $A$ and follistatin in the APR?

Given the complex nature of the APR and its importance for the ability of the body to respond to infection and trauma, it is not surprising that regulatory systems exist which set this process in motion and which, in turn, can limit its duration and extent. It has been recognised that the proinflammatory cytokines, IL-1, IL-6 and TNF $\alpha$, are involved in the activation of the APR (Fig. 1). This brief review indicates that activin $\mathrm{A}$, by its capacity to antagonise the actions of IL-1 and IL-6, represents an important modulator of the APR. This regulation is likely to occur at the site of injury and also at the liver. In turn, given the multifunctional role of activin A, its stimulation of follistatin at many sites provides a regulatory system to limit the duration of the actions of activin. It is clear that further 
work is required to test these hypotheses in whole animal experiments. Such studies would be enhanced by the availability of mice in which the relevant genes had been inactivated by homologous recombination. Unfortunately, the follistatin and activin A gene 'knock outs' do not survive significantly beyond birth (Matzuk et al. 1995a,b). Further, the design of such experiments is curtailed by the very limited supplies of these proteins.

\section{References}

Brosh N, Sternberg D, Honigwachs-Sha'anani J, Lee BC, Shav-Tal Y, Tzehoval E, Shulman LM, Toledo J, Hachman Y, Carmi P, Wen J, Sasse J, Horn F, Burstein Y \& Zipoi D 1995 The plasmacytoma growth inhibitor restrictin-P is an antagonist of interleukin 6 and interleukin 11. Identification as a stroma-derived activin A. Journal of Biological Chemistry 270 29594-29600.

ten Dijke P, Miyazono K \& Heldin CH 1996 Signaling via heterooligomeric complexes of type I and type II serine/threonine kinase receptors. Current Opinion in Cell Biology 8 139-145.

Eramaa M, Hurme M, Stenman U-H \& Ritvos O 1992 Activin A/erythroid differentiation factor is induced during human monocyte activation. Journal of Experimental Medicine $\mathbf{1 7 6}$ 1449-1452.

Fang J, Yin W, Smiley E, Wang SQ \& Bonadio J 1996 Molecular cloning of the mouse activin $\beta_{\mathrm{E}}$ subunit gene. Biochemical and Biophysical Research Communications 228 669-674.

Hare AS, Clarke G \& Tolchard S 1995 Bacterial lipopolysaccharideinduced changes in FOS protein expression in the rat brain: correlation with thermoregulatory changes and plasma corticosterone. Journal of Neuroendocrinology 7 791-799.

Hedger MP, Drummond AE, Robertson DM, Risbridger GP \& de Kretser DM 1989 Inhibin and activin regulate $\left[{ }^{3} \mathrm{H}\right]$ thymidine uptake by rat thymocytes and 3T3 cells in vitro. Molecular and Cellular Endocrinology 61 133-138.

Hubner G, Hu Q, Smola H \& Werner S 1996 Strong induction of activin expression after injury suggests an important role of activin in wound repair. Developmental Biology 173 490-493.

Hubner G, Brauchle M, Gregor M \& Werner S 1997 Activin A: a novel player and inflammatory marker in inflammatory bowel disease. Laboratory Investigation 77 311-318.

Klein R, Findlay JK, Clarke IJ, de Kretser DM \& Robertson DM 1993 Radioimmunoassay of FSH-suppressing protein in the ewe: concentrations during the oestrous cycle and following ovariectomy. Journal of Endocrinology 137 433-443.

Klein R, Clarke IJ, Hedger MP \& Robertson DM 1996 Plasma follistatin concentrations increase following lipopolysacharide administration in sheep. Clinical and Experimental Pharmacology and Physiology 23 754-755.

Kozian DH, Ziche M \& Augustin HG 1997 The activin-binding protein follistatin regulates autocrine endothelial cell activity and induces angiogenesis. Laboratory Investigation 76 267-276.

de Kretser DM \& Robertson DM 1989 The isolation and physiology of inhibin and related proteins. Biology of Reproduction 40 33-47.

Matzuk MM, Kumar TR, Vassalli A, Bickenbach JR, Roop DR, Jaenisch R \& Bradley A 1995a Functional analysis of activins during mammalian development. Nature 274 354-356.
Matzuk MM, Lu N, Vogel H, Sellheyer K, Roop DR \& Bradley A $1995 b$ Multiple defects and perinatal death in mice deficient in follistatin. Nature 374 360-363.

Michel U, Schneider O, Kirchhof C, Meisel S, Smirnov A, Wiltfang J \& Rieckmann P 1996 Production of follistatin in porcine endothelial cells: differential regulation by bacterial compounds and the synthetic glucocorticoid RU 28362. Endocrinology 137 4925-4934.

Michel U, Shintani Y \& Nau R 1998 Serum follistatin concentrations are increased in patients with septicaemia. Clinical Endocrinology $\mathbf{4 8}$ 413-417.

Nakamura T, Takio K, Eto Y, Shibai H, Titani K \& Sugino H 1990 Activin-binding protein from rat ovary is follistatin. Science $\mathbf{2 4 7}$ 836-838.

Ohguchi M, Yamato K, Ishihara Y, Koide M, Ueda N, Okahashi N, Noguchi T, Kizaki M, Ikeda Y, Sugino H \& Nisihara T 1998 Activin A regulates the production of mature interleukin- $1 \beta$ and interleukin-1 receptor antagonist in human monocytic cells. Journal of Interferon and Cytokine Research 18 491-498.

Phillips DJ \& de Kretser DM 1998 Follistatin: a multifunctional regulatory protein. Frontiers in Neuroendocrinology 19 287-322.

Phillips DJ, Hedger MP, McFarlane JR, Klein R, Clarke IJ, Tilbrook AJ, Nash AD \& de Kretser DM 1996 Follistatin concentrations in male sheep increase following sham castration/castration or injection of interleukin 1 $1 \beta$. Journal of Endocrinology 151 119-124.

Phillips DJ, de Kretser DM, Pfeffer A, Ng Chie W \& Moore LG 1998 Follistatin has a biphasic response but follicle stimulating hormone is unchanged during an inflammatory episode in growing lambs. Journal of Endocrinology 156 77-82.

Plotsky PM, Kjaer A, Sutton S, Sawchenko PE \& Vale W 1991 Central activin administration modulates corticotropin-releasing hormone and adrenocorticotropin secretion. Endocrinology 128 $2520-2525$

Russell CE, Hedger MP, Brauman JN, de Kretser DM \& Phillips DJ 1999 Activin A regulates growth and acute phase proteins in the human liver cell line, HepG2. Molecular and Cellular Endocrinology 148 129-136.

Sawchenko PE, Plotsky PM, Pfeiffer SW, Cunningham ET, Vaughan J, Rivier J \& Vale W 1988 Inhibin $\beta$ in central neural pathways involved in the control of oxytocin secretion. Nature 334 615-617.

Shao L-E, Frigon NL, Sehy DW, Yu AL, Lofgren J, Schwall R \& $\mathrm{Yu}$ J 1992 Regulation of production of activin A in the human marrow stromal cells and monocytes. Experimental Hematology 20 $1235-1242$.

Steel DM \& Whitehead AS 1994 The major acute phase reactants: C-reactive protein, serum amyloid $\mathrm{P}$ component and serum amyloid A protein. Immunology Today 15 81-88.

Yamashita N, Nakajima T, Takahashi H, Kaneoka H, Mizushima Y \& Sakane T 1993 Effects of activin A on IgE synthesis and cytokine production by human peripheral mononuclear cells. Clinical and Experimental Immunology 94 214-219.

Yu EW, Dolter KE, Shao L-E \& Yu J 1998 Suppression of IL-6 biological activities by activin A and implications for inflammatory arthropathies. Clinical and Experimental Immunology 112 126-132.

Yu J \& Dolter K 1997 Production of activin A and its roles in inflammation and hematopoiesis. Cytokines, Cellular and Molecular Therapy 3 169-177.

Received 25 November 1998

Accepted 3 February 1999 